 \\ $\frac{2}{\text { The Royal Palace Massacre, Conspiracy Theories }}$ and Nepali Street Literature
}

\section{Michael Hutt}

This is an account of a relationship between rumours and conspiracy theories on the one hand and the production and consumption of Nepali popular literature on the other. It focuses first on the rumours that circulated in Nepal during 2001 as alternative explanations for the Narayanhiti Palace massacre that took place on 1 June that year. It then describes how believers in these rumours seized upon 'errant data' in the official account of the massacre and built them up into conspiracy theories over the years that followed. Finally, it examines the way in which a number of Nepali authors capitalized on the Nepali public's fascination with this event and its continued scepticism of the official account.

\section{Rumours and Conspiracy Theories}

Rumours are 'claims of fact'. They possess credibility not because they are supported by direct evidence but because other people seem to believe them and because they fit with people's prior convictions (Sunstein, 2009, 6). They spread through two interrelated processes. The first is a social or information cascade in which people believe the views passed on to them by others because they have no information of their own. If they are predisposed to believe in a particular rumour, the rumour will spread ever more rapidly. This is especially true in conditions of social stress or unrest or in the aftermath of a crisis, when numerous speculations will be on offer:

To some people, these speculations will be plausible, perhaps because they provide an outlet for outrage and blame. Terrible events produce outrage, and when people are outraged, they are all the more likely to accept rumours that justify their emotional states, and also to attribute those events to intentional action (Sunstein, 2009, 16).

Thus, a rumour about the 'truth' of a terrible event that provokes anger and outrage may be believed because it not only relieves the 'primary emotional urge' 
that is the person's reaction to it, but also offers an explanation for the event itself that is in line with that person's biases and preconceptions.

The second process is one of group polarization, in which groups of likeminded people get together to discuss an issue on which they essentially agree, and emerge from that discussion thinking a more extreme version of what they thought before (Sunstein, 2009,7-9). Such a group will from the very beginning have a low threshold for accepting the rumour in question, but through their numbers and the force of their conviction they may also convince originally neutral people, who have a higher threshold, and even some sceptics.

Sometimes a body of rumours develops into a connected narrative, which possesses sufficient internal coherence to merit the title of 'conspiracy theory'. Conspiracy theories have been defined as 'a form of political discourse whose underlying form is the hypothesis, in which speculation fills in what is not known'(Anderson, 1996, 96) and as proposed explanations of a historical event 'in terms of the significant causal agency of a relatively small group of persons - the conspirators - acting in secret' (Keeley, 1999, 116). Conspiracy theories always claim that the conspirators' true intentions were nefarious and that the 'truth' is a well-guarded secret, even if the perpetrators are well-known public figures. The conspiracies they propose are characterized by 'secrecy, vulnerability to defeat by exposure and one or more of a combination of illegality, deception, betrayal of legitimate purposes of authorized activity, and contradiction of generally accepted moral codes of behaviour' (Hellinger, 2003, 209).

Conspiracy theories invariably run counter to a received or 'official' account. They are generally more unified than the explanations with which they must compete, and they possess greater 'explanatory reach' because they can explain not only the data contained in the received account but also all the data that the received account leaves unexplained and all of the rumours that it leaves unaddressed. Moreover, they contrast the openness and sincerity of those who believe them with the secrecy and artifice of those who are trying to cover up the truth (Waters, 1997, 115).

The adherents of conspiracy theories are regularly accused of being averse to the idea of chance in history, of over-rationalizing the world, of attributing all happenings to the direction of concealed forces and seeking purposive explanations where none exists (Waters, 1997, 113; Keeley, 1999, 126). In the world of the conspiracy theorist, nothing happens by accident, except perhaps the discovery of the conspiracy itself (Anderson, 1996, 99). The popularity of the phrase 'paranoid style', coined by Richard Hoftstadter in a discussion of American politics first published in 1965 , led for many years to conspiracy 
theories being treated first and foremost as psychological phenomena or dismissed as mere pathology (Anderson, 1996; Hellinger, 2003, 204). However, in his brief but persuasive essay on Middle Eastern conspiracy theories, Jon W. Anderson argues that conspiracy theories deserve more respect, describing them as 'fundamentally sociological, not psychological, phenonema'(Anderson, 1996, 96); another key study characterizes them as 'ethnosociologies' (Waters, 1997). Rather than concluding that all conspiracy theorists are deluded or paranoid, it may be more productive to consider the social conditions in which conspiracy theories arise and the uses to which they are put. Indeed, there may often be truth in suspicions of power. Power 'does, without a doubt, conspire' and the suspicious may be 'paranoid within reason' (West and Sanders, 2003, 15).

Conspiracy theories thrive in conditions of social exclusion where there is a widespread sense of powerlessness and mistrust (Hellinger, 2003, 216), and under systems where the level of political transparency and popular participation in decision-making is low. They are nourished and supported by certain master narratives concerned with matters that everyone is assumed to know and believe, regardless of whether they can be objectively verified. They are 'spun in highly public settings' and exhibit a high degree of interpretive confidence (Anderson, 1996, 98-99). They can also be powerful factors for political mobilization:

Against the claim that they are always disempowering, I argue that conspiracy theories sometimes serve popular resistance and empowerment because they cast suspicion on the transparency and legitimacy of actions undertaken by the police, military and intelligence agencies, whose missions include actually undertaking conspiracies (Hellinger, 2003, 205; see also Waters, 1997, 123; Wolff, 1950, 34).

\section{The Narayanhiti Palace Massacre}

On the evening of Friday 1 June 2001 [19 Jeth 2058], King Birendra and the whole of his immediate family were either killed or fatally injured by gunfire while they were attending their customary monthly dinner gathering at the Narayanhiti palace in Kathmandu. King Birendra, Queen Aishwarya, their younger son Nirajan and their only daughter Shruti were pronounced dead at the Birendra Military Hospital shortly after the incident. Their elder son, Dipendra, was declared king as he lay in a coma, but was then pronounced dead on 4 June. Five other relatives also died of gunshot wounds, including Dhirendra 
Shah, one of Birendra's two younger brothers. Over the following days the news spread quickly that Dipendra had shot his parents, his two siblings and five other relations dead, injuring three others and had then shot himself in the head. Gyanendra, Birendra's only surviving brother, became king on 4 June. ${ }^{1}$

The palace retreated behind its traditional veil of secrecy in the immediate aftermath of the massacre and even attempted to spread disinformation at first. ${ }^{2}$ Radio Nepal and Nepal Television effectively closed down for some 14 hours, and only two of Nepal's daily newspapers reported the massacre the next morning. ${ }^{3}$ The fact that all of Nepal's other papers remained silent on the matter was not because they had not received any information. Rather, according to the media analyst Rama Parajuli, 'this was due to the complexity of the subject, which meant that the dangers [involved in reporting it] had not been evaluated' (Parajuli, 2002, 53). However, the foreign and internet media began to run the story within a few hours of the event, unanimously identifying Dipendra's unfulfilled wish to marry Devyani Rana as the main causal factor.

Rumours that the absent Gyanendra, perceived as the chief beneficiary of the massacre, had some hand in planning it were lent credibility by the longstanding currency of a master narrative about his antipathy to democracy and his opposition to the concessions made by Birendra to the democracy movement of 1990 . Their positive reception was also ensured by the widespread public unpopularity of Gyanendra's eldest son Paras, who would now become Crown Prince, especially when it became known that he was present during the massacre but had escaped unhurt. Demonstrators, many with their heads shaved in mourning, came out on the streets of every major town and six were killed by police deployed to quell the protests. For several days the capital was placed under a curfew and on 4 June the body of Dipendra was conveyed to the burning ghats at Pashupati temple while its streets were all but empty. Gyanendra's ascent to the throne took place on the same day under similar conditions.

1 For a more detailed analysis of the coverage of the palace massacre by the Nepali press, see Hutt (2006). Certain sections of that article are paraphrased in what follows here.

2 One piece of obvious disinformation was that that the incident had been caused by the 'accidental' firing of an automatic weapon. This was first stated by Gyanendra on 3 June and later by a palace secretary speaking to the international media.

3 Kantipur and its English-language sister publication The Kathmandu Post each published a four page special issue on the evening of 2 June. These gave an account of what was then known of events in the palace, announced that Crown Prince Dipendra had been declared king and urged the public to remain calm. 
Immediately after he was crowned, Gyanendra announced that a high-level commission would carry out an investigation of the massacre. In the event, the commission consisted of just two people - the Chief Justice and the Speaker of the Nepali Parliament (a member of the ruling Nepali Congress Party) after the leader of the opposition, Madhav Kumar Nepal, withdrew from it. His withdrawal was said to have been prompted by objections from within his party to the fact that the commission was appointed by the palace authorities, and this probably undermined the public's trust in the commission.

The commission began its investigation on 8 June and completed it in six days. A 196-page report, consisting mainly of verbatim transcripts of interviews with eyewitnesses, was released within a week. ${ }^{4}$ The eyewitnesses all related how Dipendra had shot his parents and both of his siblings dead and had also shot eight other relatives, of whom only three survived. They also reported that he had consumed a quantity of whisky, cannabis and another unknown narcotic that evening. One eyewitness (Paras Shah) claimed that Dipendra had for some time been at loggerheads with his family (and particularly his mother) over his wish to marry Devyani Rana, the daughter of a leading Nepali politician and businessman, Pashupati Shamsher Rana. ${ }^{5}$

Rama Parajuli records that when the main findings of the official report on the Royal Massacre were presented at a press conference the assembled journalists were not permitted to ask any questions. Thus, the mainstream Nepali dailies were unable to interrogate the official account of the royal massacre, despite the fact that a huge majority of their readership was extremely distrustful of it; ${ }^{6}$ of course, this did not prevent them from identifying the gaps and contradictions in the report in the days that followed its publication.

\section{The First Rumours}

Less than two weeks after the massacre, an (American?) anthropologist sent some colleagues an email summary of the rumours that were circulating in

4 'Narayanhiti Parva: Vistrit Prativedan' [The Narayanhiti Incident: Full Report]. No date, no publisher. 'Available from 246224 Bagbazaar, Kathmandu'.

5 At the time of the massacre, Pashupati Shamsher J. B. Rana was the chairman of the Rashtriya Prajatantra or 'National Democratic' Party, which was generally seen as the most conservative and pro-palace of Nepal's parliamentary parties.

6 See Manjushree Thapa's (2002) deliberately garbled parody of the findings of the report, 'Nonsense Narrative: An Abstract History', Studies in Nepali History and Society 7 (1): 209-13. 
Kathmandu. Some of them were reports of omens. In 2000, it was said, the Royal Kumari had been asleep when the king went to receive his annual blessing from her during Indra Jatra. The fact that the population of fruit bats which roosts in the trees around Narayan Hiti palace had dramatically reduced in recent years was seen as an evil omen. After the royal funerals, on 10 June, the Kathmandu Post reported that the image of Bhimeshwor Mahadeva at a temple in Dolakha had begun to perspire four months earlier. Amid these and many other rumours, the anthropologist set out the one that she deemed the 'most tragic and widely held' and summarized as 'Dipendra did not kill his family, it's a conspiracy'.

The entire country is in a suspended state of denial. Or, as X astutely pointed out, they don't say 'this didn't happen'. They say 'we do not believe this could happen'. How could our beloved icon and a son no less kill his good father and entire family? ... though they empathize with Dipendra's quarrels with his family over his arranged marriage, they are sure this is the doings of the Black Prince who of course was predicted astrologically that he would one day re-ascend the throne. Only a lust for power would cause such a massacre. And if Gyanendra is innocent, why did he have to put curfew on so we couldn't mourn our Prince and why did they put him in a truck rather than give him a proper royal cremation procession? And why wasn't any member of the Royal family or top army brass there? ... The curfew was put on because they had to burn so many bodies. Over 100 army were shot dead - it was a military coup with Indian backing and Gyanendra as puppet - the Chinese premier just visited here and India didn't like it. ${ }^{7}$

In his book Tyo Kahalilagdo Rat (That Terrifying Night) ${ }^{8}$ published in 2007, Madhusudan Pandey provides a lengthy list of early rumours, which I paraphrase below:

- $\quad$ Prince Paras, Dr Rajiv Shahi and some army generals had conspired to selectively murder all members of the 'liberal' camp inside the palace.

- The massacre was the work of the Central Intelligence Agency (CIA) and/or the Research and Analysis Wing (RAW).

7 Email forwarded by David Gellner on 25 June 2001, headed 'Bewitching bluebloods, crying stones, sweating idols, poisonous milk and other myths'.

8 Kahalilagdo does not lend itself very easily to a one-word translation. It means 'terrifying' in the sense of the fear or sense of vertigo felt when looking down at something from a great height. 
- The killings were the work of an individual who wore a mask to disguise himself as Dipendra.

- The bullets that killed the royals were actually fired by palace security guards.

- Dipendra was shot in the back, so he could not have committed suicide.

- Dipendra was wearing national costume when he was taken to hospital, so it was not true that he had donned combat dress.

- $\quad$ Paras broke and threw away Dipendra's ventilator. ${ }^{9}$

- Hundreds were killed in the palace that night and the purpose of the curfews was to allow the disposal of their bodies.

- Films were removed from 'automatic movie cameras' at the scene of the massacres and destroyed.

- The king and queen had suffered blows to their heads from a sword and this was why no post mortems were conducted.

- The doctors at the hospital were told what to write in their reports by army generals.

- Gyanendra's absence from the family gathering proved that he was behind it; it is not true that he was in Pokhara at the time.

- The massacre had been planned by the Chief of Army Staff and a military coup had taken place.

- It was not true that Princess Komal had been injured; in fact she had been drugged and put to sleep.

- Dr Upendra Devkota [Nepal's most famous neurosurgeon] had disappeared.

- $\quad$ Prince Paras had been sent to England immediately after the massacre.

- Soldiers and police personnel were out and about in Kathmandu, dressed in plain clothes, to spread terror.

- Dipendra's bodyguard had fled and several of his friends had been arrested.

- Rajiv Shahi was under house arrest.

- Ketaki Chester was behind the massacre.

- The scene of the massacre had already been cleaned up to remove all the evidence.

- The public water supply and milk had been poisoned in Kathmandu.

9 This is (presumably) a reference to the hospital apparatus that kept Dipendra alive but in a coma until his death on 4 June 2001. 
- The king's mother had also been killed.

- The Prime Minister and leader of the opposition were in army custody.

- The ADCs (aides-de-camp) of Birendra and Dipendra had both been murdered (Pandey, 2064, 5-7).

\section{The Development of Conspiracy Theories}

To move beyond the 'paranoid-style thesis' in understanding conspiracy theory requires identification of the group(s) who hold the belief, attention to the events and circumstances that give rise to the conspiracy and serious consideration of the credibility from the point of view of the believers (Hellinger, 2003, 208; emphasis in the original).

Keeley identifies 'errant data' as the chief tool of the conspiracy theorist. In fact, a conspiracy theory invariably takes errant data as its starting point, claiming that these have been deliberately ignored by the tellers of the official story. These include 'unaccounted-for' data, i.e. 'facts' or pieces of information that are left unexplained by the official account, and 'contradictory data', i.e. data that, if true, contradict the received account of what happened (Keeley, 1999, 117-18).

It is often stated that the first step in the development of a formal conspiracy theory about the Narayanhiti massacre was taken by the Maoist leader Baburam Bhattarai. Bhattarai wrote an opinion piece entitled 'Naya kotparva lai manyata dinu hundaina' [We should not recognize the new Kot Massacre] which appeared in Kantipur on 6 June 2001, just five days after the massacre. Referring back to the Kot massacre of 1846, in which Jang Bahadur Kunwar engineered the deaths of most of his political rivals, thus inaugurating the Ranas' century of autocratic rule, Bhattarai alleged that the massacre was the result of a conspiracy involving India's Research and Analysis Wing (RAW) and unnamed 'imperialist forces'. The purpose of the massacre, he said, was to replace a patriotic king (Birendra) with one who would do India's bidding. Baburam Bhattarai praised the role played by certain members of the Shah dynasty in the preservation of Nepal's sovereignty and independence, and claimed that the Maoists and the late king had been thinking along similar lines on many questions of national importance. This was represented as an 'undeclared working unity' (aghoshit karyagat ekta) between the king and the Maoists. Bhattarai's essay ended with an implicit call to the army to mutiny against the 'puppet of expansionism born 
inside the palace', and to side instead with the 'patriotic sons of Mother Nepal who have been born in huts' ${ }^{10}$

However, Bhattarai's article was not a reaction to the official report on the massacre, because this had not yet been published, nor did it offer any coherent account of events inside the palace on 1 June. Instead, it presented an explanation for the massacre that blamed it on the geopolitical machinations of the Nepali Left's favourite bogeymen. It is therefore more accurate to characterize it as an act of political agency that sought to capitalize on the shock and fear produced by the massacre in the Nepali public mind, rather than the propagation of a conspiracy theory per se.

Nor did the mainstream Nepali dailies ever go so far as to explicitly challenge the verdict on Dipendra. Instead, they contrived to give voice to continued public doubt by regularly printing interviews and stories that attested to his good character (Parajuli, 2002, 59). The independent left writer Khagendra Sangraula took this challenge just about as far as it could go in an article entitled 'Nephew Dipendra! Forgive me!' ('Bhatij Dipendra! Malai Maph Gara') published on 7 July 2001 (Sangraula, 2001a). Sangraula wrote that although Dipendra might well have lived on Mars for all the contact he had had with him, he had observed him from afar and wondered what kind of king he might make. He saw a peaceable, civilized, cheerful man who wanted to lower the tall palace walls and come closer to the ordinary people. After he died, however, his character had been transformed into that of a person who was 'mentally ill, a harmer of others and himself, crazed with love, astonishingly cruel and an unimaginably criminal demon, a father killer, a mother killer, a brother and sister killer, an aunt and uncle killer, a killer of everyone.' Although he never knew Dipendra, Sangraula wrote, Dipendra now follows him wherever he goes, protesting his innocence, crying out that while he is being presented as the greatest murderer in history he is actually the victim of the greatest injustice in human history. ${ }^{11}$

Although Baburam Bhattarai and Khagendra Sangraula were both speculating and neither offered any evidence to support the claim that the

10 The paper's editor and the managing director and director of Kantipur Publications were arrested the very day Baburam Bhattarai's article appeared in their newspaper, and charged with treason under the Offences against the State (Crime and Punishment) Act 1989, which carried a prison term of up to three years and a fine of Rs 3,000. They were released on 15 June and by the end of September the courts had upheld the government's decision to drop all charges (Yogi, 2002, 53-54).

11 This essay appears with other poems and essays on related themes in a collection entitled Itihasma Kalo Potieko Anuhar (A Face Painted Black in History) (Sangraula, 2001b). 
massacre was the work of the Indian intelligence services (Bhattarai) or that Dipendra was being falsely accused (Sangraula), their status as, respectively, an underground insurgent leader and a well-known public intellectual lent their public expressions of disbelief credibility. It quickly became an article of faith and not just among Nepali Maoists - that Gyanendra was directly responsible for the murder of his brother. The Maoists' public statements regularly described him as 'fratricidal' and 'regicidal' (Lecomte-Tilouine, 2004).

Nonetheless, the official report contained a number of 'errant data' items and left many questions unanswered, providing an aspiring conspiracy theorist with plenty of rich material. For instance, how could an individual who was deeply intoxicated gun down twelve individuals on a highly selective basis, killing all but three? Why was it that every member of Birendra's blood line had been killed, while Gyanendra's son and daughter escaped unharmed? Why would Dipendra, who was right-handed, shoot himself in the left side of his head? What was the explanation for the statement by one eyewitness in the official report that a loud noise (described by him as ghyar ghyar and taken to refer to the sound of gunshots) could still be heard coming from the stairs leading from the billiard room to the garden even as Dipendra was being taken to hospital? How could the Nepali public believe that Dipendra, a generally popular royal who had been seen acting completely normally in public at a Sports Council function that very day, was capable of such crimes? Where was the evidence (other than a statement by the deeply distrusted Paras) to support the assertion that the marriage issue lay behind the killings? Why were the dead and injured taken not to the nearby teaching hospital, but to the military hospital on the far side of the city? In the years that followed the massacre, the prevailing public mood was one of disbelief in the official account. There was widespread suspicion that Gyanendra was in some way to blame for it, but a unified conspiracy theory had yet to emerge. As a former Maoist combatant told me in Kathmandu in July 2012,

I still don't believe that Dipendra did it. For the son of a king to kill so many people just for a girl ... none of the ordinary people (am janata) can believe this. The son of a king can marry any girl he likes. And what girl would not want to be a queen? [Perhaps a Maoist girl? I asked] No no, in this world who doesn't run around trying to secure their comforts (subidha)? ... What he could perhaps have done was commit suicide. There's a 'symptom' of this in our society these days. If a boy is really set on a girl this is one path he might go down. We've never seen anyone in Nepal wipe out their whole family, mother, father, because of a girl. Perhaps never in the world. Can people commit suicide in your country? There is very little basis for believing 
this. But please study the long history of the monarchy. Since before, the Bhandarkhal, Kotparva, these events have happened, in which brothers finished one another off. It seems to us that there might be a pattern here. Killing your brother was no big deal.

Keeley argues that it is often very difficult indeed for official storytellers to falsify a conspiracy theory once it has taken hold. When further data is presented to support the official story, a conspiracy theorist, who is operating in conditions of widespread scepticism, can easily point to this as evidence of how badly 'they' want the public to believe the official story (Keeley, 1999, 119-20). And it is true that the eyewitness accounts of the event from surviving dinner party guests that trickled out via the Nepali media over the following months largely failed to dispel public disbelief in the official version of the story - however, a coherent alternative version of events in the palace did not emerge until much later.

\section{Kathmandu Street Literature and the Royal Massacre}

The 2001 palace massacre remains a topic on which ordinary Nepalis frequently converse, and the widespread belief that the populace has not been told the truth of what really happened or why it happened is strengthened through the process of group polarization outlined above. It might be supposed that the failure of any disbeliever in the official account to produce a coherent conspiracy theory to counter it in the years since 2001 might have reduced the level of public disbelief, but this appears not to be the case. ${ }^{12}$

After five booksellers were arrested in Kathmandu on 22 June 2001, apparently for selling publications which set out alternative explanations for the palace massacre (Yogi, 2002, 55), the knowledge that the authoring or publication of books that proposed alternative accounts of or explanations for the palace massacre would expose their progenitors to legal sanction or worse appears to have had a suppressive effect. Thus, no further accounts were produced until nearly five years after the event. Conditions began to be judged to be safe after the success of the People's Movement of March-April 2006, when, although Gyanendra was still the king and his son Paras was still the crown prince, it was perceived that the monarchy was almost certainly a doomed institution.

12 Hellinger reports a similar situation with regard to conspiracy theories surrounding the assassination of John F Kennedy: the belief that the assassin was not working alone 'seems to have become more widespread with the passage of time'(Hellinger, 2003,216). 


\section{Raktakund (Pond of Blood)}

Krishna Aviral's 140-page 'historical' and 'research-based' novel Raktakund was published in November 2006. According to the cover of its third edition, published in May 2009, 135,000 copies of the book were sold during 2007. Aviral himself thinks this figure might be inflated, and estimates total sales since first publication to have been around 100,000 (interview on 4 May 2011). Whichever sales figure is true, it would appear that Raktakund was at that time by far the bestselling book published in Nepal this century. ${ }^{13}$ In autumn 2010, it could still be found on almost every pavement book stall in Kathmandu.

The reasons for its success are not difficult to identify. The unprecedented commercial success of the novel Palpasa Café, published in 2005, signalled a radical shift in the production and consumption patterns of Nepali literature, at least in Kathmandu. The state's pre-1990 near-monopoly on the print media had been broken, new independent publishers had sprung up, the size of the literate population had doubled every ten years and the economy of the Kathmandu valley saw unprecedented injections of cash, not least in the form of remittances from workers overseas. The 'historical novel'(aitibasik upanyas) had been an established genre of Nepali writing for generations, and enterprising writers now had a much larger potential readership

Aviral's book tells how its author tracked down two key informants, both former palace employees, who told him all about the scandals and intrigues within the palace walls that led to the massacre of King Birendra and his family on 1 June 2001. It then offers a new account of the massacre, which differs from the findings of the official investigation team.

The book contains numerous stories about the activities of various members of the Shah family, most of which are unflattering. To give just a few examples: Mahendra's first wife, Indra, did not really die in childbirth but was slowly poisoned for leaking the details of Tribhuvan's plot to poison senior Ranas; Ratna was sent to the UK for an abortion and sterilisation after her engagement to Mahendra; the Shahs were really Magars, not Thakuris, and the first person to state this publicly was the Nepali anthropologist Dor Bahadur Bista, who promptly disappeared; all of the Shah kings had numerous extra-marital affairs,

13 The community library at Pakribas in the Dhankuta district of east Nepal, which I visited on 14 March 2011, contains a total of 3,032 books and has a membership of 772 readers. However, its collection of Nepali literary works is very dated. For instance, it held none of the bestselling novels of the past ten years. Nonetheless, it did contain five copies of Raktakund, which had been requested by readers. Each copy had been borrowed by an average of 20 people. I thank the librarian Babita Paudel for showing me around. 
and several women who became pregnant by them were forced to miscarry; Mahendra did not die of a heart attack but committed suicide because he feared that India was about to take over Nepal; Pashupati Shamsher refused to marry Mahendra's daughter and this was the cause of the palace's later aversion to the idea of his daughter marrying Dipendra; Gyanendra is the son of Queen Ratna, not Indra; Dipendra was sent drugs via the Royal Nepalese Embassy in London while studying at Eton; the helicopter crash in which Princess Prekshya was killed on 12 November 2001 was no accident, and so on. However, the claim for which the book would become most famous came towards its end, from the mouth of the second informant, 'Shanta', who claimed to have been an eyewitness to the massacre, in which she claims her own husband also died:

I opened a curtain on a window very close to me and looked towards the Tribhuvan Sadan, there were people running here and there, and crying could be heard. I saw Dipendra Sarkar going about carrying a machine gun ... Just then Nirajan Sarkar came out and ran towards the garden. But before he had gone a few feet he was hit by a bullet and fell. I peered out through the curtain and saw that it was Dipendra Sarkar who was firing. Now I was confused. I could not work out what was happening. Because there I saw two Dipendras. One was going in and out of the door to the billiards room, another was firing at Nirajan in the garden. At that very moment the queen came out. She too was shot at in the garden, three or four times in quick succession. When the bullets hit her I saw her body fly up two or three feet. When I saw that my heart trembled. While Aishwarya Sarkar was being shot in the garden, bullets were also being fired inside the baithak room. It seems to me that another person was shooting at Shruti, Shanti, Gorakh and the others inside. After the sound of about two successive shots and crying, Dipendra Sarkar came out of a recess in the Tribhuvan Sadan itself and ran out into the garden. When I saw him I was startled, unable to identify which was the real Dipendra. But before he could reach the billiard room he was shot right there in the garden, on the bridge between the two pools. He fell down right there. After that I realised that the people I had seen before firing guns were conspirator murderers disguised as him and wearing masks (Raktakund, 118-19).

The popularity of Raktakund was due in part to its timing. The item of 'errant data' from which it takes its cue is the royal aide-de-camp Gajendra Bohara's testimony in the official report that bullets were still being fired after Dipendra had fallen, and the fact that the investigators never asked who it was that was 
firing. Aviral told me that he had two objectives when he was writing Raktakund. His first was to open up the mystery surrounding the massacre, and his second was to create a 'negative impression' of Gyanendra at a time when there was public debate about whether Nepal should retain its monarchy. He published it as a novel because he believed that forces sympathetic to the palace would have taken action against him if he had brought it out as an 'investigative report'. He admits that he took advantage of the fact that there was widespread disbelief in the official story and that he wanted to 'pull the whiskers off the dying tiger'. ${ }^{14}$ Krishna Aviral informed me that four different publishers refused to publish Raktakund and eventually he published it himself using his own funds. $\mathrm{He}$ claimed that an established publisher printed the books and undertook the task of distribution, but did not want the book to bear its imprint.

Since the publication of Raktakund, at least half a dozen more books have appeared in the Nepali marketplace which take the royal massacre as their central topic or starting point. These include Agnijwalama Darbar [The Palace in Flames of Fire] by Keshavraj Devkota (February 2007), Pardaphas [Revelation] by Salina Thapa (March 2007), Shabvanshko Shalyakriya [Surgery on the Shah Lineage] by Krishna Aviral (September 2007), Tyo Kabalilagdo Rat [That Terrifying Night] by Madhusudan Pandey (2007), Darbar Hatyakandko Rabasya [The Mystery of the Palace Massacre] by Arjun Gyawali (March 2009) and Narayanbiti Darbarra Deshbbaktako Avasan [The Narayanhiti Palace and the End of a Patriot] by Rajkumar Pokharel (2011).

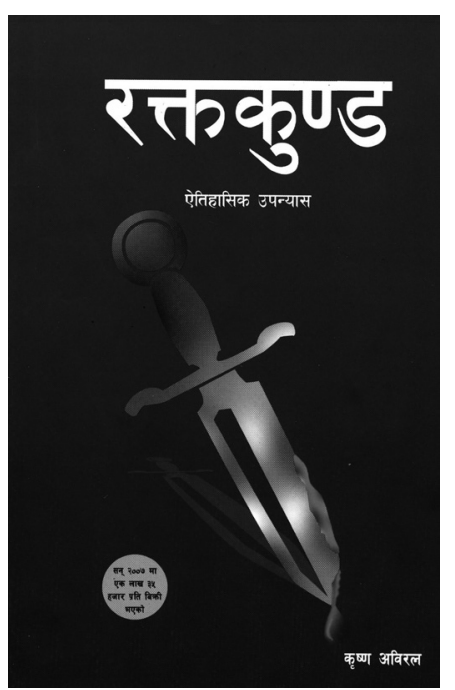

Figure 2.1: The cover of Raktakund, by Krishna Aviral. This bears the legend ' 135,000 copies sold in 2007 '.

\section{Pardaphas (Revelation)}

Pardaphas, whose author is given as 'Salina Thapa', was probably the most commercially successful of these, with at least 60,000 copies printed, and was certainly the most outrageous. Its front cover bears the following legend:

14 Krishna Aviral, recorded interview, Kathmandu, 4 May 2011. 
The Mahabaharata of the misdeeds of King Gyanendra and Paras

This is how the palace massacre happened

- The identity of the murderer who destroyed the line of King Birendra

- The hard to obtain love letters of the murdered Dipendra

- A factual account of the murders, conspiracies and licentiousness (bhogrilas) of the Shah kings

Despite its alluring cover, this 'novel' (which, like Raktakund, is described on its title page as 'research-based and historical') does not give any account of or explanation for the palace massacre until page 160 of its 163 pages. The rest of the book purports to be a memoir penned by a 'call-girl' named Salina. 'Salina' recounts her entrapment of and sexual liaisons with a wide variety of influential Nepali men, including a senior Rana army officer, a Nepali screen star, a senior Nepali Congress politician and a Maoist leader. From these and others she winkles out the 'truth' about the history of the Shahs and the goingson inside the palace. However, in several instances the author's true intention seems to be to besmirch her informants' reputations. When the narrative does at last relate the story of the palace massacre, its account is very similar to the one presented in Raktakund, though it develops this further and presents a more elaborate rationale for it.

\section{Conclusion: 'The Lower Depths of Imagination in Print'}

A shocking event occurs at the apex of a society that is already fearful and distrustful of the authorities; the authorities produce an account and explanation of the event that contains contradictions and errant data; rumours circulate and are spun into alternative explanations that play on popular prejudices and suspicions; an enterprising author seizes the moment and produces a book that at last spins a conspiracy theory and gives it a literary articulation; and, unsurprisingly, the book sells well. In his seminal book Literature, Popular Culture, and Society (1961), Lowenthal writes,

The academic disciplines which have been traditionally charged with the history and analysis of literature have been caught unaware by the impact of mass literature, the best seller, the popular magazine, the comics and the like, and they have maintained an attitude of haughty indifference to the lower depths of imagination in print. A field and a challenge have thus been left open and the sociologist will have to do something about it (Lowenthal, 1961, 141). 
The range of literature offered for sale by Kathmandu sellers gives an interesting indication of what sells at this level of the book market, not least because many of the books are provided by publishers on a sale or return basis. In March 2012 I photographed stalls at Bag Bazaar and Ratna Park and under the famous pipal tree on New Road. Raktakund, which was ubiquitous only two years earlier, could not be seen in any of these locations - perhaps the abolition of the Shah monarchy had lessened its saleability. ${ }^{15}$ But its popularity until just a year or two earlier reflects a dramatic playing out in reality of a model of conspiracy theory

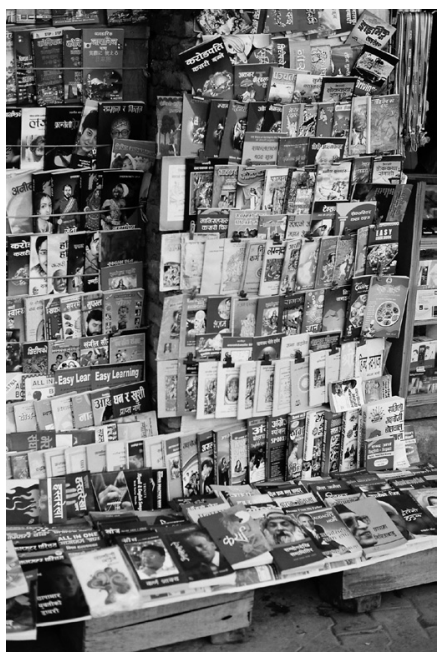

Figure 2.2: Pavement literature stall near Ratna Park, Kathmandu, 2012. development that was forged mainly in American political contexts. The commercial success enjoyed by this book is indicative of the low level of political transparency that has always existed in Nepal - not just under the monarchy, but also under the supposedly 'democratic' post-panchayat dispensation. The official explanation for the massacre was produced hurriedly, and with little sense of the urgent political need to present the Nepali public sphere with some kind of coherent truth. In the absence of any such account, unconvinced public actors made up their own, and later flocked to read a rendering of what they already half-believed when it appeared in published form.

\section{References}

Anderson, Jon W. 1996. 'Conspiracy Rheories, Premature Entextualization, and Popular Political Analysis', Arab Studies Journal 49 (1): 96-102.

Aviral, Krishna. [2063] 2066. Raktakund (Khojma Adharit Lilamay Upanyas) [Pond of Blood: A Playful Research-based Novel]. Kathmandu: Dubo Prakashan.

15 The great outpouring of sorrow over Birendra's death and the posthumous surge in his popularity might well have been linked as much to the unpopularity of his younger brother as to any reappraisal of the dead king's character and legacy. Bandita Sijapati points out that very little was done in Nepal to mark the tenth anniversary of the massacre, 'when one would have expected some sort of remembrance of a king who had been able to arouse so much emotion in his death' (here I am quoting from Sijapati's written comments on an earlier draft of this chapter). 
Hellinger, Daniel. 2003. 'Paranoia, Conspiracy and Hegemony in American Politics'. In Transparency and Conspiracy, edited by Harry G. West and Todd Saunders, 204-32. Hutt, Michael. 2006. 'Things That Should Not Be Said: Censorship and Self-Censorship in the Nepali Press Media 2001-2', The Journal of Asian Studies 65 (2): 361-92.

Keeley, Brian L. 1999. 'Of Conspiracy Theories', The Journal of Philosophy 96 (3): 109-26. Lecomte-Tilouine, Marie. 2004. 'Regicide and Maoist Revolutionary Warfare in Nepal: Modern Incarnations of a Warrior Kingdom', Anthropology Today 20 (1): 13-19.

Lowenthal, Leo. 1961. Literature, Popular Culture, and Society. Palo Alto: Pacific Books.

Pandey, Madhusudan. 2064. Tyo Kahalilagdo Rat [That Terrifying Night]. Kathmandu: Pairavi Prakashan.

Parajuli, Rama. 2002. 'Narayanhiti Hatyakanda: 'Brodshit'ko Kabharej' [The Narayanhiti Massacre: 'Broadsheet' Coverage]. In Midiyako Antarvastu: Vividha Vishleshan (Media Content: Various Analyses), edited by Pratyoush Onta, Ramesh Parajuli and Rama Parajuli, 49-71. Kathmandu: Martin Chautari/Samajik Vikas tatha Anusandhan Kendra.

Pokharel, Rajkumar. 2011. Narayanbiti Darbar ra Desbbbaktako Avasan. [The Narayanhiti Palace and the End of a Patriot]. Kathmandu: Oriental Prakashan Griha.

Sangraula, Khagendra. 2001a. 'Bhatij Dipendra! Malai Maph Gara' [Nephew Dipendra! Forgive Me!], Kantipur Koseli (7 July). 2001b (2058 v.s., Saun). Itihasma Kalo Potieko Anuhar [A Face Blackened in History]. Kathmandu: Antarkriya Prakashan.

Sunstein, Cass. 2009. On Rumours: How Falsehoods Spread, Why We Believe Them, What Can Be Done. London: Allen Lane.

Thapa, Salina. 2063. Pardaphas. Khojmulak Aitihasik Upanyas [Revelation. A Research-based Historical Novel]. Kathmandu: Dikura Prakashan.

Waters, Anita M. 1997. 'Conspiracy Theories as Ethnosociologies: Explanation and Intention in African American Political Culture', Journal of Black Studies 28 (1): 112-25.

West, Harry G. and Todd Sanders (eds). 2003. Transparency and Conspiracy: Ethnographies of Suspicion in the New World Order. Durham and London: Duke University Press.

Wolff, K. H. 1950. The Sociology of Georg Simmel. New York: Free Press.

Yogi, Bhagirath (ed). 2002. Status of Press Freedom and Freedom of Expression: Nepal Report 2002. Kathmandu: Center for Human Rights and Democratic Studies (CEHURDES). 